\title{
塗装による表面の平滑化と外観
}

\author{
森 田操* \\ The Surface Smoothing with Paint-Coating and its Effect on Appearance \\ Misao MORITA*
}

Key Words : Surface Profile, Surface Smoothing, Appearance of Coating, Distinctness of Image, Image Clarity

\section{1. 塗装外観と表面形状}

塗装外観を問題にする場合，色彩と並んで，質感（テ クスチャー）を考慮する必要があり，近年ますます，質 感の向上が要請されている。質感のなかであ, 光沢感, 平滑感は比較的明確に認識でき, かつ人による認識の違 いが少ない重要な感覚であるが, 塗膜の表面形状は, こ れらの感覚に大きな影響を与えている。

表面形状が与える外観感覚は, 塗膜面における形状の 波長域により異なっており, 表面形状と外観との関係を 考える場合には，このことを考慮する必要がある。さら に, 人の外観感覚表現や，その形状の成因をも考慮すれ ば，次のように分類することができる。

一短波長（数 $10 \mu \mathrm{m}$ 以下）

目視では形状認識できず, 光沢感の低下や, 塗膜面 に写った像のコントラストの低下のような光学的特 性として認識される。

一中波長（数 $100 \mu \mathrm{m} \sim$ 数 $10 \mu \mathrm{m}$ )

乾燥硬化時の樹脂収縮のような, 比較的小さな形状

で, ウジ感, ムジ感等の表現がなされている。

一長波長 (数mm 数 $100 \mu \mathrm{m}$ )

スプレー塗装時のゆず肌に代表される比較的大きな 形状で, 塗面に入射する光の正反射方向が変化する ため, 塗膜面に写った像の形の歪みとしても認識さ れる。

\section{2. 表面形状の評価方法}

塗膜面の表面形状は，触針式の接触型装置により測定 されるのが一般であるが, 自由表面として形成された塗 膜表面は一般には図 $1^{1}$ ) に示すように種々の波長の波成 分を含んでいるので, 塗膜外観との関係を考える場合に は, 前述したように, 波長域にわけて評価する必要があ

*日本ペイント(侏技術センター（干572 大阪府寝屋川市池田中 町19-17, 0720-27-1111)

Technical Centnr, Nippon Paint Co.,Ltd. (19-17, IkedaNakamachi, Neyagawa-shi,Osaka 572)

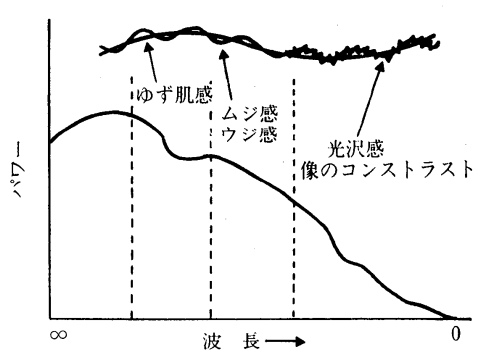

図1 塗膜表面形状と塗膜表面断面曲線のパワースペクトル (モデル)

る。このために, 塗膜表面の断面曲線のパワースペクト ルを求め特定波長区間のパワースペクトの和を評価値と して用いる場合が多い。

\section{3. 塗膜外観の評価方法}

最近の自動車塗装や, 一部の家電製品の塗装のような 優れた外観を評価するには, 従来からよく用いられてい る鏡面光沢計などは差異検出能力がないために使用でき ない。これからの優れた外観の評価には, 従来は塗膜面 に写る文字や図形パターンなどの鮮明さ（写像鮮明性） により外観を目視評価するPGD計などが用いられてい た。

しかしこれらの評価法む, 目視評価であるための個人 差があることや, 個人の視力の限界があること, 高水準 の外観の差異検出能力が低いこと, 写像鮮明性低下の 2 大要因である像のコントラストの低下と像の形の歪みと の分離が不可能であること等の問題がある。

そのため筆者らは, 测定対象面による反射を介して拡 大結像した微細な縞パターンの像のコントラストを代表 するパラメータ（NSIC* 值）と像の形の歪みを代表す るパラメータ（NSIC值）とを分離して定量的に評価す ることが可能なNSIC計 (NSIC=Nippon-Paint SugaShikenki Image Clarity)を開発しこれによる評価を 提案している棌。 


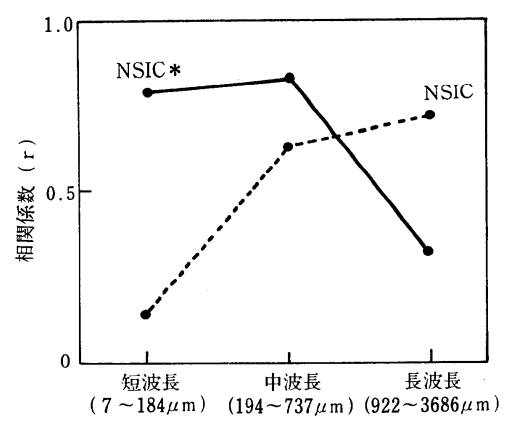

図 2 写像鮮明性と塗膜表面断面のパワースペクトル和 との相関

\section{4. 塗膜表面形状と 外観（写像鮮明性）との関係 ${ }^{4}$ )}

筆者らは, 塗膜の表面形状と写像鮮明性との関係につ いて種々検討しているがその一部を図 2 に示す。図 2 の デー夕は自動車上塗り用赤色塗料をべースとして, 艶消 し剂配合量や，塗装方法を変えて作成した種々の表面形 状を持つ塗膜の表面を，3 次元表面形状測定機により測 定し, その断面曲線を周波数解析し, 各波長領域のパワー スペクトル和と, NSIC * 值, NSIC值との相関係数を 表わしたものである。

短波長領域の粗さは像のコントラストを代表するNSI $\mathrm{C} *$ 值への寄与が大きいこと, 長波長領域の形状は像の 形の歪みを代表するNSIC值への寄与が大きいこと，ま た中波長領域の形状は，NSIC * 值，NSIC值双方に寄 与することを表わしている。

\section{5. 塗装による鋼板面の平滑化 ${ }^{5,6)}$}

近年, 塗装面の持つ光沢感, 平滑感等の外観特性の重 要性が増してくるにつれて, 塗装外観に与える鋼板素地 の表面形状への影響についての検討がなされている。

異なる表面形状を持つ32種の冷延鋼板とめっき鋼板に 化成処理，電着塗装，中塗り，上塗りを施した試料を用 いて，各塗装ステージにおいて表面形状を測定し，塗膜 表面の断面曲線のパワースペクトルの平方根（振幅に相 当）を求め，塗装によるその值の減少率を 32 種の鋼板の 平均值を用いて表示したものを図 3 示す。図 3 には，電 着塗装による平滑化効果，中・上塗り塗装による平滑化 効果, 全塗装系の平滑化効果が示されている。

図3に見られるように，この塗装系では電着塗装と中・ 上塗り塗装とでは平滑化効果は異なるが, 全塗装系とし ては200〜700 $\mu \mathrm{m}$ の波長でほぼフラットな平滑化効果を 持ち，それより大きな波長では平滑化効果が減少するこ とが認められる。

また図 4 に，前記のNSIC值に対する表面形状の寄与

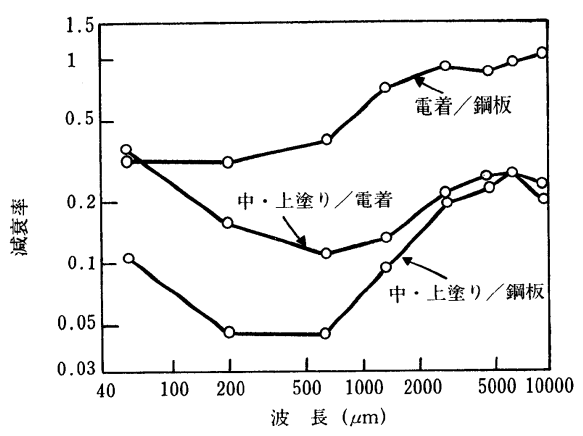

図 3 塗装による表面形状の振幅減衰率

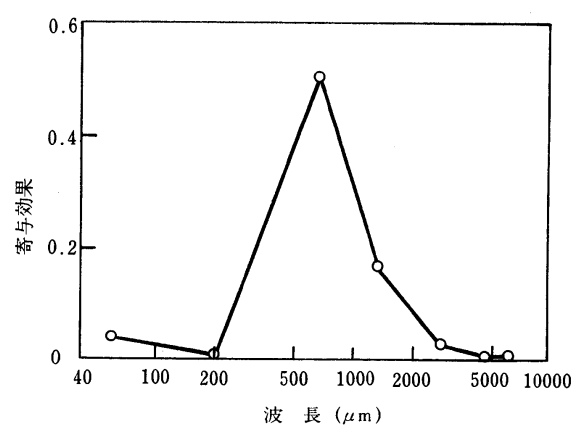

図 4 上塗りの表面形状の写像鮮明性への寄与効果

効果の解析結果を示すが， 500 1000 $\mu \mathrm{m}$ で寄与が極大 となることが認められる。

これらを総合すれば，このような塗装系においてはN SIC値への寄与が大きく, かつ塗装による平滑化効果が あまり期待できない500〜2000 $\mu \mathrm{m}$ の波長の形状を鋼板 表面で少なくすることが重要であることを示している。

\section{6. おわりに}

塗膜の光沢感, 平滑感等の外観感覚之, 塗膜表面形状 とについて, 両者の関係, その評価方法, 改善のアプロー チについて述べた。今後は, 光沢感, 平滑感以外の, 我々 の知覚している各種の感覚と光学的物性との関連や, そ のような光学的物性を発現するモデルの検討等により, 質感を解析し，その向上を図っていく必要がある。

(1988-11-24 受理)

\section{文献}

1) 桑野浩一, 中島孝司 ; 色材研究発表会要旨集, p. 152 (1986)

2 ) 中島孝司, 森田 操 ; 塗装工学, 20, (2),50,(1985)

3) 森田 操, 中島孝司; 色材研究発表会要旨集, p. 198 (1986)

4) 未発表

5 ）中島孝司他; 色材研究発表会要旨集, p. 202,(1986)

6 ) Takashi Nakajima et al.; Proc. XIVth Int. Conference in Coatings Sci. and Tech., p. 227(1988) 